Reply

\title{
Reply to Comment by Alison A. Monaghan, David A.C. Manning, and Zoe K. Shipton on 'Repurposing Hydrocarbon Wells for Geothermal Use in the UK: The Onshore Fields with the Greatest Potential, by Watson et al. (2020)'
}

\author{
Sean M. Watson *(D), Gioia Falcone and Rob Westaway (1) \\ James Watt School of Engineering, University of Glasgow, Glasgow G12 8QQ, UK; gioia.falcone@gla.ac.uk (G.F.); \\ robert.westaway@gla.ac.uk (R.W.) \\ * Correspondence: s.watson.3@research.gla.ac.uk
}

Received: 11 September 2020; Accepted: 1 December 2020; Published: 3 December 2020

check for updates

Keywords: geothermal energy; repurposing hydrocarbon wells; UK resource assessment

\section{Reply:}

Monaghan, Manning, and Shipton [1] allege 'factual inaccuracies around the purpose of the UK Geoenergy Observatory in Glasgow (GGERFS)' in the Energies paper by Watson et al. [2]. They also object to the mention in [2] of the cost of this project and the 'use of an estimated figure from [our] own work for the resource size, prior to any borehole testing'.

Before addressing their comment, we note that these authors each have a key role in the Glasgow Geothermal Energy Research Field Site (GGERFS) project, something they might reasonably have noted in their comment: Monaghan is GGERFS 'Science Lead' [3]; Manning is 'Senior Science User' for the UK Geoenergy Observatories (UKGEOS), whose duties (in relation to UKGEOS sites including the GGERFS) include 'facilitating engagement between the British Geological Survey (BGS), who are delivering the project, and the wider science community' [4]; and Shipton chairs the Geoenergy Science Advisory Group which produced the UKGEOS science plan, of which the GGERFS is a major component [5]. Such relationships raise the possibility of conflict of interest regarding objective discussion and should have been declared in accordance with the procedures described to potential authors in this journal.

The aim of the Watson et al. paper [2] was to assess potential (theoretical) heat outputs of onshore hydrocarbon wells in Britain if repurposed for geothermal heat production. To illustrate the potential importance of this heat source, comparison was made with minewater geothermal heat projects, which was presented (in Figure 11 of [2]) as a plot of thermal power output versus source temperature for a range of existing or potential projects. The GGERFS was one of the minewater geothermal heat sites selected for this comparison, with the accompanying unambiguous statement that 'The GGERFS is a test site for minewater geothermal heat production $[6,7]$ and is not currently used for heat production or storage (hence its inclusion here as a 'potential' site)'. Although a full economic assessment of the cost of geothermal repurposing of onshore hydrocarbon wells was outside the scope of [2], as part of providing background details and project contexts some economic data were mentioned, including the EUR 55 million cost of the Rittershoffen geothermal project in eastern France and the GBP 9 million budget for the GGERFS. Monaghan et al. [1] state that 'The cost of the [GGERFS] Observatory includes boreholes and compounds for research incorporating numerous sensors, a wide range of open data including environmental baseline boreholes and monitoring 
equipment, a contribution to IT infrastructure for open data etc.' However, they do not provide a reference for the corresponding budget itemisation, the BGS being the developer and operator of both the GGERFS site and the associated monitoring and data dissemination infrastructure. Of course, other geothermal energy projects also collect large scientific datasets, but the funding model for data dissemination may be different. For example, the Centre de Données de Géothermie Profonde (CDGP; Deep Geothermal Data Centre) at the University of Strasbourg, which archives data from projects in eastern France, is funded in part by site operators and in part by the French Ministry of Research and Education [8,9]. In any case, itemisation of the overall GGERFS budget is immaterial to the results and conclusions of Watson et al. [2] and there cannot be any cause of misunderstanding by future GGERFS users, given the previously cited statement in [2] that 'the GGERFS is a test site for minewater geothermal heat production and is not currently used for heat production or storage', with due citation of GGERFS open reports (e.g., [6,7,10]).

The GGERFS was thus plotted as a 'potential minewater geothermal site' in Figure 11 of [2], with a $12{ }^{\circ} \mathrm{C}$ source temperature and an $\sim 8 \mathrm{~kW}$ estimated thermal power output. Watson et al. [2] made clear by citation of Watson and Westaway [11] that this potential $\sim 8 \mathrm{~kW}$ estimate was for the sustainable thermal power output that might be achieved if particular GGERFS wells were to be used for groundwater production and reinjection, and was based on a simple calculation reported by [11]. Since similar simple calculations were applied to many other sites to create Figure 11, this was a fair comparison. Monaghan et al. [1] note that the design of the GGERFS has not been optimised for heat production. This is evidently so, having indeed been noted previously [12], but it is also true for most of the other projects plotted in Figure 11 of [2] and so is likewise a fair comparison: oilfield infrastructures have been designed and operated to optimise oil production; mine dewatering schemes have been designed to facilitate mineral production or to keep the water table low to avoid surface pollution in abandoned coalfields.

In summary, the Watson et al. [2] Energies paper correctly summarizes the purpose of the GGERFS minewater geothermal heat project, correctly reports the budget for this project, and correctly and fairly reports the only published estimate for its potential (theoretical) thermal power output.

Author Contributions: Writing—original draft preparation, R.W.; writing—review and editing, G.F. and S.M.W. All authors have read and agreed to the published version of the manuscript.

Funding: The Watson et al. [2] study was funded by UK Research and Innovation through EPSRC-CESI grant number FFC1-024.

Conflicts of Interest: The authors declare no conflict of interest.

\section{References}

1. Monaghan, A.A.; Manning, D.A.C.; Shipton, Z.K. Comment on 'Repurposing hydrocarbon wells for geothermal use in the UK: The onshore fields with the greatest potential. Watson et al. (2020)'. Energies 2020, 13, 6373. [CrossRef]

2. Watson, S.M.; Falcone, G.; Westaway, R. Repurposing hydrocarbon wells for geothermal use in the UK: The onshore fields with the greatest potential. Energies 2020, 13, 3541. [CrossRef]

3. BGS. Dr. Alison Monaghan; British Geological Survey: Nottingham, UK, 2020; Available online: https://www.bgs. ac.uk/staff/profiles/2445.html (accessed on 5 September 2020).

4. UKRI. UK Geoenergy Observatories Project Appointment of Senior Science User; UK Research and Innovation: Swindon, UK, 2018. Available online: https://nerc.ukri.org/funding/available/capital/ukgeos/senior-science/ (accessed on 5 September 2020).

5. Shipton, Z.K. We Need to Change Our Energy Systems Profoundly to Tackle Environmental Challenges; UK Geoenergy Observatories, British Geological Survey: Nottingham, UK, 2018; Available online: https://www.ukgeos.ac.uk/blog/uks_top_earth_scientists (accessed on 5 September 2020). 
6. Monaghan, A.A.; Dochartaigh, B.O.; Fordyce, F.; Loveless, S.; Entwisle, D.; Quinn, M.; Smith, K.; Ellen, R.; Arkley, S.; Kearsey, T.; et al. UKGEOS—Glasgow Geothermal Energy Research Field Site (GGERFS): Initial Summary of the Geological Platform; Open Report OR/17/006; British Geological Survey: Nottingham, UK, 2017; 205p, Available online: http://nora.nerc.ac.uk/id/eprint/518636/13/OR17006.pdf (accessed on 25 June 2020).

7. Monaghan, A.A.; Starcher, V.; Dochartaigh, B.O.; Shorter, K.; Burkin, J. UK Geoenergy Observatories: Glasgow Geothermal Energy Research Field Site Science Infrastructure; Open Report OR/18/037; British Geological Survey: Nottingham, UK, 2018; 46p, Available online: http://nora.nerc.ac.uk/id/eprint/521444/1/OR_18_037_GGERFS_ Science_infrastructure_reportv8.pdf (accessed on 25 June 2020).

8. Schaming, M.; Fremand, A.; Cuenot, N.; Dalmais, E.; Girard, J.-F.; Grellier, C.; Grunberg, M.; Schmittbuhl, J. How to Deal with Old and Industrial Data? The Example of the Data Center for Deep Geothermal Energy (CDGP). In Proceedings of the European Geosciences Union General Assembly 2018, Vienna, Austria, 8-13 April 2018; Available online: https://presentations.copernicus.org/EGU2018/EGU2018-17425_presentation.pdf (accessed on 5 September 2020).

9. CDGP. The Project; Centre de Données de Géothermie Profonde: Strasbourg, France, 2020; Available online: https://cdgp.u-strasbg.fr/project.html (accessed on 5 September 2020).

10. Monaghan, A.A.; Starcher, V.; Dochartaigh, B.O.; Shorter, K.; Burkin, J. UK Geoenergy Observatories: Glasgow Geothermal Energy Research Field Site: Science Infrastructure Version 2; Open Report OR/19/032; British Geological Survey: Nottingham, UK, 2019; 49p, Available online: http://nora.nerc.ac.uk/id/eprint/522814/1/OR_19_032_ GGERFS_Science_infrastructure_reportv11.pdf (accessed on 5 September 2020).

11. Watson, S.M.; Westaway, R. Borehole temperature log from the glasgow geothermal energy research field site: A record of past changes to ground surface temperature caused by urban development. Scott. J. Geol. 2020, 56, 134-152. [CrossRef]

12. Optimat. GGERFS Company Demand Analysis; Report J3120; Optimat Limited: East Kilbride, UK, 2019; 37p, Available online: http://www.evaluationsonline.org.uk/evaluations/Documents.do?action=download\&id= 943\&ui=basic (accessed on 5 September 2020).

Publisher's Note: MDPI stays neutral with regard to jurisdictional claims in published maps and institutional affiliations.

(C) 2020 by the authors. Licensee MDPI, Basel, Switzerland. This article is an open access article distributed under the terms and conditions of the Creative Commons Attribution (CC BY) license (http://creativecommons.org/licenses/by/4.0/). 